Florida International University FIU Digital Commons

FIU Electronic Theses and Dissertations

University Graduate School

$11-7-2012$

\title{
Students' Perspective of the Role of Facebook in their Studies
}

Frank A. Rojas

Florida International University, frank.alexander.rojas@gmail.com

DOI: $10.25148 /$ etd.FI13040401

Follow this and additional works at: https://digitalcommons.fiu.edu/etd

\section{Recommended Citation}

Rojas, Frank A., "Students' Perspective of the Role of Facebook in their Studies" (2012). FIU Electronic Theses and Dissertations. 815. https://digitalcommons.fiu.edu/etd/815

This work is brought to you for free and open access by the University Graduate School at FIU Digital Commons. It has been accepted for inclusion in FIU Electronic Theses and Dissertations by an authorized administrator of FIU Digital Commons. For more information, please contact dcc@fiu.edu. 


\title{
FLORIDA INTERNATIONAL UNIVERSITY
}

Miami, Florida

\section{STUDENTS' PERSPECTIVE OF THE ROLE OF FACEBOOK IN THEIR STUDIES}

\author{
A thesis submitted in partial fulfillment of \\ the requirements for the degree of \\ MASTER OF SCIENCE \\ in \\ HIGHER EDUCATION ADMINISTRATION \\ by \\ Frank Alexander Rojas
}


To: Dean Delia C. Garcia

College of Education

This thesis, written by Frank Alexander Rojas, and entitled Students' Perspective of the Role of Facebook in their Studies, having been approved in respect to style and intellectual content, is referred to you for judgment.

We have read this thesis and recommend that it be approved.

Joy Blanchard

Eric Dwyer

Benjamin Baez, Major Professor

Date of Defense: November 7, 2012

The thesis of Frank Alexander Rojas is approved.

Dean Delia C. Garcia College of Education

Dean Lakshmi N. Reddi University Graduate School

Florida International University, 2012 
(C) Copyright 2012 by Frank Alexander Rojas All rights reserved. 


\section{ACKNOWLEDGMENTS}

I would like to acknowledge all that have helped me through this learning experience. Specifically, I wish to thank my professors who served on the committee: my advisor, Dr. Benjamin Baez, for his guidance and great support with this project; Dr. Joy Blanchard for her selflessness and many words of wisdom; and Dr. Eric Dwyer for his encouragement and words of wisdom.

My heartfelt thanks to my former supervisor, Jason Chokel. He provided me with the support that I needed while I worked for Residential Life. I would also like to thank Angel Reyes; she helped me deal with the challenges that were present in 2011-2012. Also, I would like to thank my supervisor, Dr. Hilary Landorf. She gave me support and guidance to taking the research a step forward.

I cannot go without mentioning the love from my parents and siblings. My mother sacrificed her life to provide me the opportunity for an education, and for that I am truly grateful. To my cousin, Sindy Juliet Arizmendy Cano, thank you for understanding my point of view and helping relate it to others in our family. Last, but not least, I would like to

thank all the participants who took part in this research. Without you, this study would have been impossible. 


\title{
ABSTRACT OF THE THESIS \\ STUDENTS' PERSPECTIVE OF THE ROLE OF FACEBOOK IN THEIR STUDIES \\ by
}

\author{
Frank Alexander Rojas \\ Florida International University, 2012 \\ Miami, Florida \\ Professor Benjamin Baez, Major Professor
}

The purpose of this thesis was to study the students' perspective on their use of Facebook to further their studies. There were three research questions: (1) To what extent do students use Facebook to further their studies? (2) In what ways do students use Facebook to further their studies? (3) What do students believe are the ways that Facebook can be used by colleges and universities to help students with their studies?

There were three major themes relating to usage of Facebook: non-academic usage, curricular, and co-curricular. Most of the students indicated they used Facebook to stay in touch with people they already knew. With regard to academic usage, the answers given related mostly to professors' offers of support, collaborations with projects and assignments, and cheating on exams. There were mixed responses about whether students wanted professors to make use of Facebook in classes and how, with many indicating that they wanted to keep Facebook separate from their curricular activities. Students that were in the education fields were more than willing to use Facebook to help them in their studies than students in other majors. 


\section{TABLE OF CONTENTS}

CHAPTER

PAGE

1

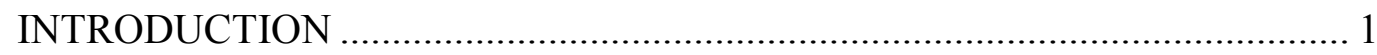

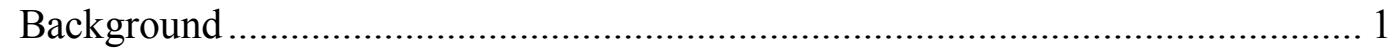

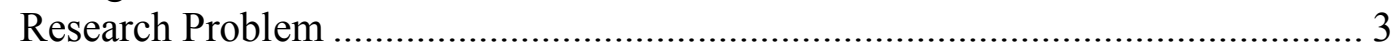

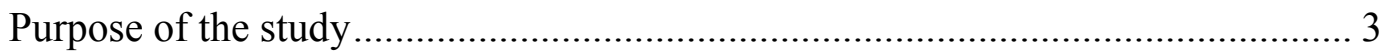

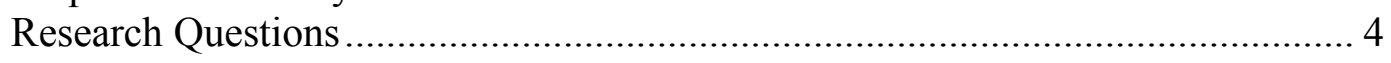

Rationale and Significance of the Study ............................................................ 4

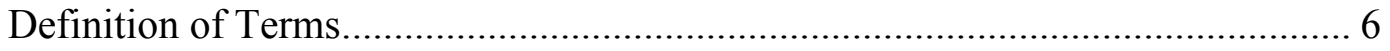

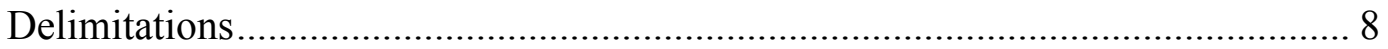

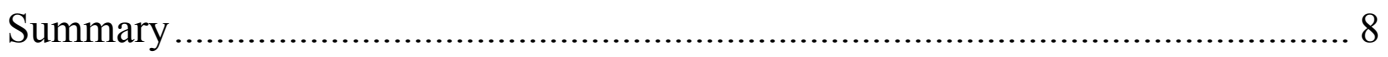

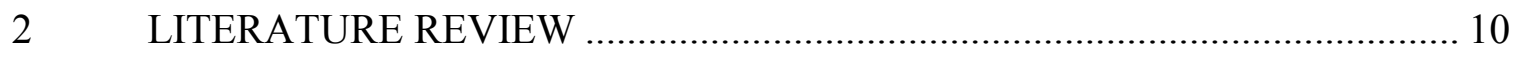

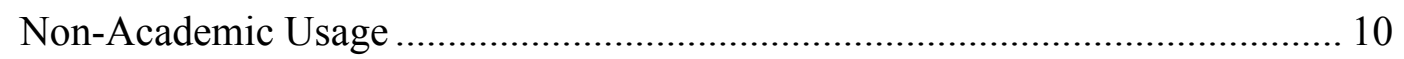

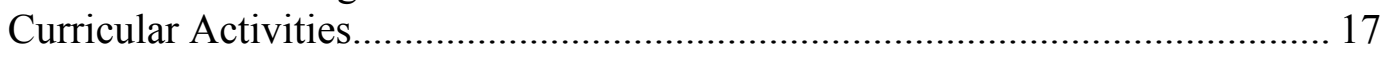

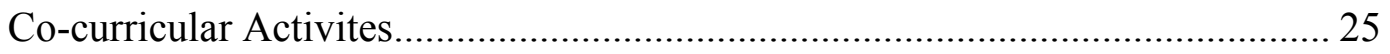

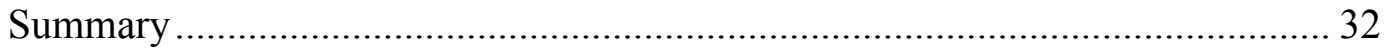

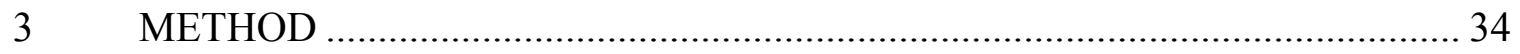

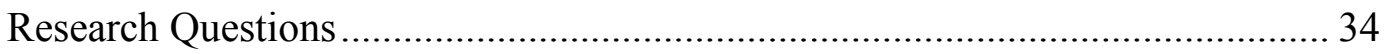

Research Design................................................................................... 34

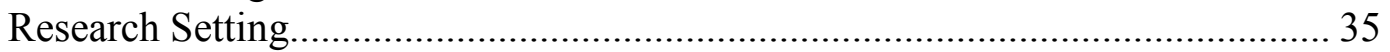

Population and Sample ……………………………….................................. 35

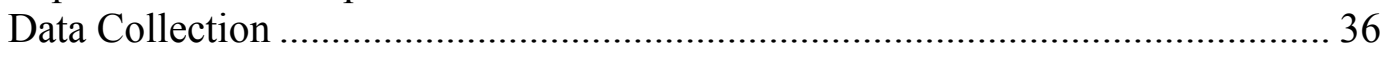

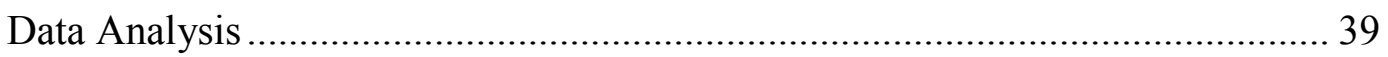

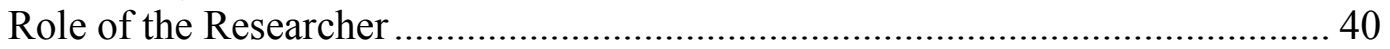

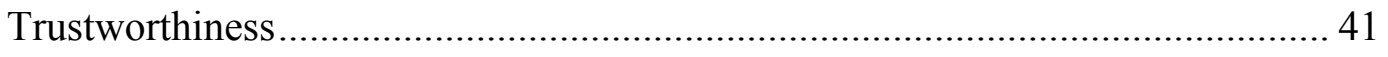

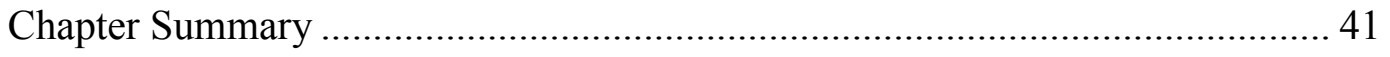

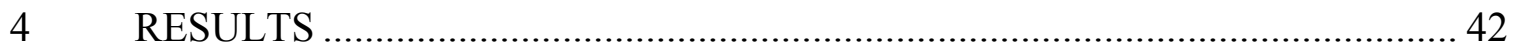

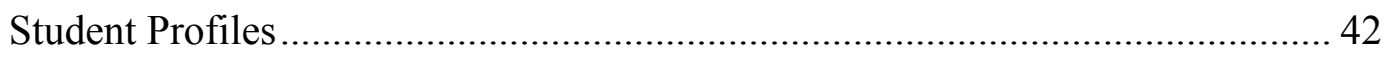

Non-Academic Usage by Students ................................................................... 45

Academic Usage by Students....................................................................... 47

Professor Involvement ............................................................................... 50

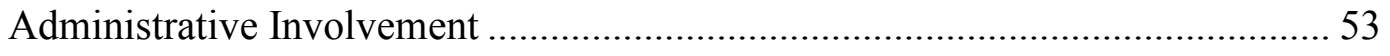

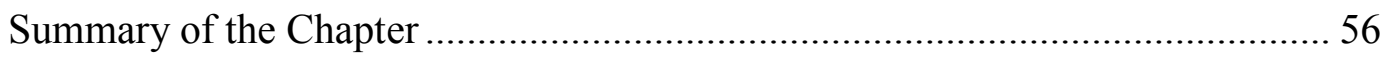

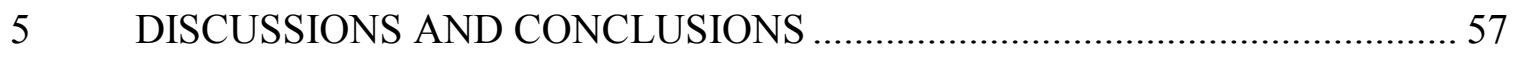

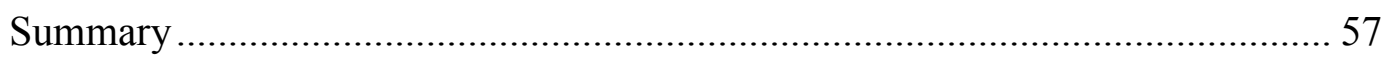

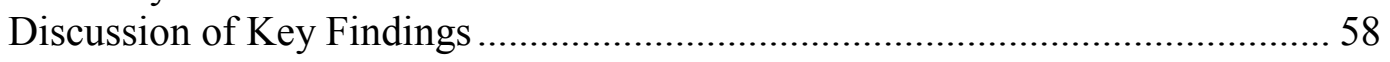

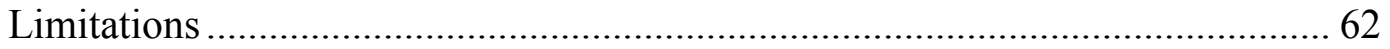

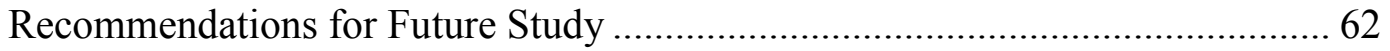

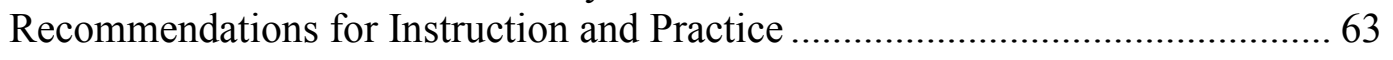


Conclusion ....

REFERENCES 


\section{CHAPTER 1}

\section{INTRODUCTION}

Technological changes occur every day, and technological advancements change the way humans communicate with each other (Dawson, 2010; Elster, 2010; Seufferheld \& Scagnoli, 2011). Social networking sites (e.g., Web 2.0) are relatively new forms of communication in which individuals create virtual profiles and form networks with friends, family, co-workers, and others (Ajjan \& Hartshorne, 2008; Boyd \& Ellison, 2008; Mazer, Murphy, \& Simonds, 2007). Facebook is one of the most popular social networking sites (Khan \& Jarvenpaa, 2010), and there are 700 million active users on Facebook (Facebook, 2012). A large portion of students are using Facebook as a mean of communication. For example, several universities in the Midwest United States reported that $91 \%$ of the students surveyed were using Facebook (Khan \& Jarvenpaa, 2010; Teclehaimanot \& Hickman, 2011). Pempek, Yermolayeva, and Calvert (2009) reported that about $55 \%$ of Facebook users log into Facebook website several times a day to integrate their thoughts, feelings, and behaviors.

\section{Background}

Colleges and universities have used social networking sites for a variety of purposes. For instance, college administrators at Ithaca College, Middlebury College, Mars Hill College, and the University of Florida have used Facebook groups, profiles, and pages to promote their departments, services, and recruitment initiatives (David, 2010; Joly, 2007; Villano \& Gullon, 2009). The faculty and staff at the University of Florida claimed to have increased their graduate admissions because of the implementation of a Facebook program in which faculty and staff talk to prospective 
graduate students through Facebook group discussions about graduate programs (David, 2010). To date, however, few empirical studies address how effectively students or institutions of higher education are using social media. This thesis focuses on one kind of social media: Facebook.

A few empirical examples exist of how colleges and universities have used Facebook for improving their services and operations. For instance, Morris, Reese, Beck, and Mattis (2010) found that Facebook use among students could help with retention. Bowers-Campbell (2008) suggests that instructors should create Facebook profiles and facilitate student contacts via chat rooms. Contacting students via Facebook can encourage self-efficacy among the students and motivate them to learn. Another study suggests a perceived educational value in using Facebook because it can be used for communication, collaboration, and as a resource (Mazman \& Usluel, 2010). Similarly, Connell (2009) indicates that college or university staff and faculty can advertise their departments' news and events in a Facebook profile.

A few studies have provided specific examples on how Facebook has helped students. According to Schroeder and Greenbowe (2009), Iowa State University had issues with participation in their introductory chemistry laboratory courses. The researchers compared WebCT and Facebook usage. The results were that the students preferred using Facebook over WebCT for their discussions. Another study (McCarthy, 2010) found that a semester of using Facebook as part of a FYE curriculum helped students who were more introverted and had language barriers. Also, most of the students gained academic connections. Hung and Yuen (2010) found that students had positive responses toward Ning, another popular social networking site. The students saw Ning as 
a good supplement in their course and showed positive learning outcomes. A few other studies have provided evaluations of whether the usage of Facebook helped or hindered students’ progress (Hung \& Yuen, 2010; McCarthy, 2010; Schroeder \& Greenbowe, 2009).

\section{Research Problem}

Few studies provide definitive empirical data on how students use Facebook or the effectiveness of their use of Facebook in promoting their academic studies. Clearly, given the prominence of Facebook in young people's lives, more empirical studies are warranted about whether Facebook offers an outlet for simply social interaction or whether Facebook also promotes their academic studies.

\section{Purpose of the Study}

The purpose of the research was to study how students use Facebook to further their studies. This research is important because institutions appear to be using social networking to recruit and retain students. Yet currently little empirical evidence exists indicating whether students even use such technology to further their studies or what they believe might be good institutional uses for social media with regard to their academic programs.

This thesis sought to offer qualitative evidence of whether and how students use Facebook to further their academic studies and how students think institutions of higher education might use Facebook to help students with their studies. The purpose of this thesis is to provide the student perspective of the ways students use Facebook for their studies. 


\section{Research Questions}

Based on interviews with students, this study aimed to answer three primary research questions:

1) To what extent do students use Facebook to further their studies?

2) In what ways do students use Facebook to further their studies?

3) What do students believe are the ways that Facebook can be used by colleges and universities to help students with their studies?

\section{Rationale and Significance of the Study}

Knowing how students use Facebook can be beneficial to faculty and staff. The study relies on student experiences using Facebook for curricular and co-curricular activities and their perspectives of its application for their learning. Because there is almost no literature on the topic of Facebook in a higher education setting, interviewing students is an appropriate way of gaining knowledge (Seidman, 2006).

Knowing to what extent and in what ways Facebook has been used by students in their studies can help the researcher understand their "lived experiences" (Seidman, 2006, p. 9). These student experiences can also be useful for faculty and administrators to incorporate Facebook to curriculum.

Using the three research questions, the researcher was trying to understand the meaning the students make of their experiences (Seidman, 2006). If students had prior experiences using Facebook for their classes, it would be appropriate to know what their experiences were. Even if the student did not have such experiences, knowing what they thought of the use of Facebook for their classes would allow faculty and staff to know the students' opinion to develop an appropriate curriculum. 
The goal of higher education professionals is to produce students that are intentional learners who can adapt to new environments, think critically, and continue to learn as they progress in life (NASPA, 2004). To accomplish this goal higher educational professionals have to be able to get to know their students and meet them where they are (Chickering \& Reisser, 1993; Perry, 1981; Kolb, 1984; NASPA, 2004). The few studies that exits have given the administrator or faculty perspective of how Facebook should be used in a higher education setting. However, it would be best to know the students' perspective on how they think Facebook should be used to further their studies.

Traditionally, faculty and administrators use e-mails, Blackboard, Moodle, Microsoft Office, and other classroom technologies to help them teach their students. Furthermore, faculty would build relationship with students by having office hours, communicating through emails, or staying after class. To form relationships, faculty and staff would need to know their students. Facebook has the potential to build relationships and provide another venue to learning because this medium allows students to integrate their thoughts, feelings, and behaviors (Pempek et al., 2009).

Yet, students could have different levels of comfort when knowing their professors are on Facebook. One study found that the professors' sex and age could influence the levels of appropriateness among male and females students (Teclehaimanot \& Hickman, 2011). Knowing the ways students use Facebook academically can allow faculty and staff to develop a curriculum that is relevant to the student's perspective, facilitate discussions among students outside of the classroom, and allow for different levels of learning experiences (Chickering \& Reisser, 1993; Perry, 1981; Kolb, 1984). 
Knowing the student perspective would allow faculty and staff adopt a curriculum that can relate best to their students.

\section{Definition of Terms}

Curricular activities are academic instructions that allow for the acquisition of content from a classroom environment, laboratory, small group research, capstone integrative courses, and academic clubs. This is also not limited to art exhibits, drama, theater, and music productions (NASPA, 2004).

Co-curricular activities are activities that are primarily focused on leadership development, career development, and interpersonal development. These activities apply what has been taught in class to real life experiences. This allows the student to experience different avenues of learning. This is typically done with programming by student affairs professionals, faculty, staff, and community organizations (NASPA, 2004). It is hoped that the results of this study might be useful for researchers and higher education practitioners expanding their knowledge of students.

Poke is an action on Facebook. The option is available for anyone who wants to send a gesture of kindness to a friend on Facebook. The user can click on their friend's page and send them a poke. The friend is notified about the poke (Facebook, 2012).

Post is an action on Facebook. Post is when a person wants to share a picture, send a small message, send an article, a video, or other forms of media to their own or a friend's profile, or on group's page. When someone posts something, it is meant to be open to the public (Facebook, 2012). 
Instant messaging is similar to a post. However, in instant messaging, the user is sending the item privately. Also, with instant messaging, the user can have instant conversation, similar to text messaging on a cellular phone (Facebook, 2012).

Timeline is a relatively new feature on Facebook. In early 2012, Facebook revamped the user interface of the profile. Posts have been rearranged according to the year and month of their submissions.

Newsfeed is another feature on Facebook. When a user logs on, or initializes Facebook through a cell phone, the user sees the newsfeed feature. The newsfeed provides live updates of their friends' actions. The user can control how often, what, and who they want to see through the options settings.

Tag is an action on Facebook where the user decides to post something and wants others to see it. The user begins by writing the names of their friends. Facebook will automatically find the profiles associated with the name. If the user is tagging a friend on a picture, then Facebook has a tag option and you can touch any portion of the picture. Once a portion has been selected the user can find their friend by typing their name. Once the tag is complete and posted, the friend or friends are notified of the tag. If the friend does not want to associate with a post, the user can untag themselves from the post (Facebook, 2012).

Wall referrers to the space in the user profile where posts are posted for public viewing (Facebook, 2012).

Friending is the action where one locates a person on Facebook and asks the user if they want to be associated with each other on Facebook. The other user either agrees or ignores the request. If the user agrees to the request, then the one asking for the request is 
notified that both parties are friends. The act of friending is also made public on both accounts.

Groups are a Facebook page that is associated with a real organization or an online group. Similar to a user's page, the group can post items and have discussions. The difference is that a Facebook group page is administered by a small group of people or just by one. Other Facebook users can join a group and if there is any activity in the group, the users associated with the group will be notified of the activity. Each post will also count and display who has seen it (Facebook, 2012).

\section{Delimitations}

This study focused on the students' perspective on how Facebook should be used for their studies. The student participants came from Florida International University, so application of the study results to students elsewhere must be speculative. The research is qualitative in nature, so its generalizability relates to its ability to describe detail experiences that others might deem similar to theirs.

\section{Summary}

Few empirical examples exist of how colleges and universities have used Facebook for improving their services and operations. A few studies have provided specific examples on how Facebook has helped students and none on the student perspective of how Facebook can be used to enhance their learning. Given the prominence of Facebook in young people's lives, more empirical studies are warranted about whether Facebook offers an outlet for simply social interaction. The purpose of the research was to study how students use Facebook to further their studies. Knowing to what extent and how Facebook has been used by students can help the researcher 
understand their "lived experiences" (Seidman, 2006, p. 9). These experiences have also shaped up their perspectives of how faculty and administrators should use Facebook in curriculum design and teaching.

The study contains five chapters. Chapter 2 provides a review of the literature. There are no direct literature on the topic of student perspectives and its relationship with the usage of Facebook for curricular and co-curricular purposes. However, there is enough literature to divide the chapter into three sections: (a) Non-academic uses, (b) curricular activities, and (c) co-curricular activities. Chapter 3 describes the phenomenological framework and methods of data collection, analysis, and management. Chapter 4 presents the findings. Chapter 5 contains responses to the research questions and implications for research and practice. 


\section{CHAPTER 2}

\section{LITERATURE REVIEW}

In this chapter, a review of the literature relevant to the usage of Facebook in an educational setting is provided. The chapter is divided into three sections: (a) NonAcademic uses, (b) curricular activities, and (c) co-curricular activities. It concludes with a summary. There is no current literature on the student perspective of how Facebook should be used by faculty and administrators for their studies. Furthermore, most of the studies are quantitative, which is not the method used in this study. For the purpose of generalizability, the researcher included where the studies were conducted.

\section{Non-Academic Usage}

The increasing literature on Facebook has provided some insight into the specific use that students get out of Facebook. Some studies have discussed levels of appropriateness of communication between faculty and students, gender differences, frequency and type of usage, and motivation for online presence (Clipson, Wilson, \& DuFrene, 2012; Drumheller, Hanson, Teclhaimanot \& Hickman, 2011; Judd \& Kennedy, 2010; Junco, 2012; Koles \& Nagy, 2012; Malesky, Jr., \& Peters, 2011; Mallard, McKee, \& Schlegel, 2011; Quan-Haase \& Young, 2010; Wodzicki, Schwammlein, \& Mosakaluik, 2012).

\section{Level of Appropriateness and Gender Differences}

Teclehaimanot and Hickman's (2011) study helps to develop an understanding of what students see as appropriate in student-teacher interactions on Facebook. The study used students that were enrolled in selected courses at the College of Education at the 
University of Toledo. There were a total of four classes, two were undergraduates while the remaining other two were graduate level classes.

The results indicated that students found passive behaviors (e,g., reading or viewing posts) to be more appropriate than active behaviors; students were uncomfortable with poking their teachers and having their teachers poke them. Students were uncomfortable at commenting at items posted by their teachers and having their teachers comment on the students' posts. There seems to be some variability in what students consider appropriate and inappropriate when teachers send friend invitations. There was a significant difference between male and female students; male students found student-teacher interactions on Facebook to be more appropriate than the female students (Teclhaimanot \& Hickman, 2011). To determine if self-disclosure could have an impact, Mazer, Murphy, and Simonds (2007) tested this idea with 133 undergraduates, mostly freshmen. After a simple frequency distribution gender was found to not affect their perceptions.

The results of these quantitative studies (Mazer et al., 2007; Teclhaimanot \& Hickman, 2011) showed differences; however, they do not reveal what the students were thinking while answering the surveys (Seidman, 2006). Another critique about the Techlaimanot and Hickman's (2011) study is that they did not take into account the effects of the gender of the professors. Although, Teclhaimanot and Hickman (2011) did acknowledge that the gender of the professor could have influenced the results, the degree of this impact is unknown.

Malesky, Jr. and Peters (2012) conducted another study on the opinions of university students and faculty members about the faculty-student interaction on social 
networking sites. Their survey of 459 students and 159 faculty members at a midsize public university in the Southeastern United States found that 180 students and 46 professors answered no to, "do you think it is appropriate for professors to have accounts on online social networking sites such as Facebook and Myspace? p. 142" There was a significant difference between female (40\%) and male students (30.8\%) who responded no. Similarly, more students than faculty answered no.

Upon further analysis, Malesky Jr. and Peters (2012) found that students rated "looking up students out of curiosity as to who would be in his or her class the upcoming semester; professor used social networking sites to learn more about his/her students before the semester started; professor attempted to verify the veracity of a student's excuse for missing an exam; professor looked up a student in his or her class that he/she thought was attractive, p. 142" as significantly inappropriate. The only scenario that the students found appropriate was when the professor used social networking sites to learn student names.

The professors rated "professor contacted student to inform him/her about extra credit opportunities; professor looked up a student in his or her class that he/she thought was attractive, and professor used social networking sites to send course related messages to students," as significantly inappropriate. The faculty rated "professor used social networking sites to try and find out why a name on the roster of new students sounded familiar, and professor used social networking site to facilitate learning the names of his or her students,” as significantly appropriate (Malesky, Jr., \& Peters, 2012, p. 142).

Malesky, Jr., and Peters (2012) also had an open ended question asking students and faculty to write additional thoughts on the use of social networking sites. The 
answers were grouped by the consensus of two clinical psychology graduate students. The most common theme by faculty was that it was "fair game" for anyone who wants to look up for information. Another theme was that the faculty believe it is best to communicate and facilitate learning with student over email and Blackboard than other electronic sources. Students indicated that professors' intentions to look up student information were critical, disagreed about using Facebook for personal or academic learning, and believed it was unprofessional for professors to check on student information on Facebook.

Malesky, Jr., and Peters (2012) had a qualitative data analysis in their study that involved an open-ended question. Contrary to Malesky Jr. and Peters's (2012) study, the researcher in this study did face-to-face interviews and recorded the sessions for transcription. Using the interview method, the researcher was able to capture the emotions and possibly more data because students did not have to write down their thoughts.

Overall there is no consistency about what students find inappropriate when faculty use any social networking websites for their classes. Teclhaimanot and Hickman (2011) found that students find it appropriate for professors to use Facebook for passive behaviors while Malesky, Jr., and Peters (2012) showed student dissatisfaction with professors using social networking sites to check on students. None of these studies take into consideration the ethnicity of the students. 


\section{Frequency and Type of Usage of Social Networking Sites}

Koles and Nagy's (2012) studied 42 university students in Budapest, Hungary. Out of the 42 students, $60 \%$ visited Facebook at least two times a day; $50 \%$ of the participants have over 300 Facebook friends.

Hanson et al. (2011) conducted a study on the competing demands of today's college students. The researchers surveyed 294 participants (139 were freshman, 97 were sophomores, 40 were juniors, 17 were seniors; females consisted of $60.2 \%$ while males consisted of 39.8\%). It is important to know that these students came from a regional Southwestern university and consisted primarily of speech and mass communications courses. Based on the time diary results the students spent an average of 5.43 hours a week on Facebook.

Kolek and Saunders (2008) conducted a study on student self-disclosures on Facebook. The authors used a quantitative content analysis of Facebook profiles. Kolek and Saunders coded the profiles and proceeded to categorize the profiles; 464 profiles were randomly analyzed: $25 \%$ were freshman, $22.4 \%$ sophomore, $24.4 \%$ junior, and $28.2 \%$ senior. The study acknowledged the limitation of using student from a Northeast public institution. Women were more likely to use Facebook, than men, $88 \%$ and $77 \%$ respectively. This is consistent with other studies on gender and Facebook (Clipson, Wilson, \& DuFrene, 2012; Hanson et al., 2011; Junco, Merson, \& Salter, 2010). The difference between Kolek and Saunders' study and this study is that in this study interviews were the primary source of data collection. The researcher attempted to establish a reppport with the participants and reduce chances of dishonest answers. Also, interviews helped the researcher understand student answers. 
Kolek and Saunders (2008) stated that $11.3 \%$ of the profiles were blocked; the rest of the study was conducted using sample of 339. Men were more than likely to post their phone number on their profiles than women. However, female students were more or as likely to disclose information about themselves in terms of general contact information, references and pictures to alcohol, drugs, and parties, and references to the institution, have an "about me" section, have one or more photo albums, image of self in central photography, references to learning.

\section{Motivation for Online Presence}

Quan-Haase and Young (2010) conducted a study on the motivation and gratification for using Facebook, specifically on undergraduate students. Seventy-seven students from an undergraduate communications class at a large research Canadian university were recruited for this study. The students were heavy users of Facebook; 82\% logged into their accounts several times a day. Through interviews, students logged in between two to five times a day. Each session lasted about 5-15 minutes. Each session was used to check and respond to messages, view photographs, and check on updated activities from their friends. During the time of the study the top four reasons why individuals joined Facebook were, "friend suggested it" (85\%), "everyone I know is on Facebook" (49\%), "help others keep in touch with me" (46\%), and "find classmates" $(18 \%)$. The need to belong with the group and stay in contact with others seems to be a major theme in motivation for students to have adopted Facebook (Quan-Haase \& Young, 2010, p. 355).

The study identified six factors for continuing use of Facebook. For passing time students stated to "kill time", "because it is entertaining", and "to put off something I 
should be doing" as their top three; the other factors included affection to others and were "to let people know I care about them" and "to show others encouragement". A lot of students did mention that they used Facebook "to feel involved with what's going on with other people" (Quan-Haase \& Young, 2010, p. 356).

What Quan-Haase and Young (2010) found was that students joined Facebook because other students told them about it and wanted to fit in; the students continued using Facebook as a way to entertain or distract themselves and in some sense to know what others were doing and stay connected with them. A concern of this would be that one cannot generalize to students outside of Canada where the study was conducted. However, these results are similar to those in Ellison, Steinfield, and Lampe's (2007) study on Facebook and social capital.

A total of 286 undergraduate students from Michigan State University participated in an online survey (Ellison et al., 2007). Just like in previous studies (Clipson, Wilson \& DuFrene, 2012; Hanson et al., 2011; Junco, Merson \& Salter, 2010; Quan-Haase \& Young, 2010), most participants (66\%) were female. No information was given to the class they belonged to and their majors. Each participant roughly had 151200 friends on Facebook from the university and spent about 10-30 minutes on Facebook a day. One of the major results of the study was that most of the students used Facebook to keep in touch with their current contacts, similar to Quan-Haase and Young (2010) results.

Teclhaimanot \& Hickman (2011), Malesky Jr. and Peters (2012), and Kolek and Saunders (2008) provided some insight into gender difference. However, none of the studies compared classes, majors, and undergraduate vs. graduate students. 


\section{Curricular Activities}

Effects of Facebook on curricular activities are discussed in terms of GPA and learning. Current studies found that there is a negative relationship between Facebook usage and GPA and students do not want to Facebook for curricular purposes. There is literature stating that the adoption, purpose, and perception of Facebook can have an impact on the usage of Facebook for curricular purposes.

\section{Effects on GPA}

The current literature on the effects of Facebook on student academic performance is limited. Kabre and Brown (2011) did a study on the influence of Facebook on academic performance and the quality of life of college students. Kabre and Brown (2011) surveyed 209 students from a historically Black university in the southern United States. The students came from different disciplines. Most of the participants were of African descent (88\%), 57.9\% were females, 35.9\% were freshmen, $13.4 \%$ sophomores, $20.1 \%$ were juniors, and $30.6 \%$ were seniors. The results indicated no significant relationship between hours spent on Facebook and academic performance and between student perception of Facebook and academic performance. It is important to note that because this was a self-response survey, there could have been some underlying issues that affected the results. The study also lacked a control group.

Kirschner and Karpinski (2010) performed an in depth analysis and comparison of Facebook users and non-Facebook users. Kirschner and Karpinski surveyed 219 students, 102 undergraduate and 117 graduate. The survey contained opened and closed response items. 
Kirchner and Karpinski (2010) said that the low representation of freshmen and sophomore were appropriate because they did not want to include possible confounding variables, such as acclamation and changes of major. However, it is still important to gather their perspective to know what these students were thinking (Chickering \& Reiser, 1993). Kirchner and Karpinski (2010) found that Facebook users and non-users were significantly different. Facebook users had lower GPAs and spent less time studying than non-Facebook users. There were no significant differences on the status of the student, undergraduate or graduate.

An open ended question was asked to the participants, "Has Facebook had an impact on your academic performance?" Kirchner and Karpinski (2010) found that $26.2 \%$ of the students reported an impact; most of these students indicated a negative impact. The users with a negative impact stated that they were procrastinating and easily distracted by Facebook. These users also had poor time management skills. For those students with positive impacts, Facebook was used to form study groups or as another form of communication with their peers.

\section{Learning}

Facebook has been used (or can be used) in formal setting to teach students. Mazman and Usluel (2010) developed an educational model explaining how students could use Facebook for learning. This model consists of 14 variables. Adoption of Facebook is better explained with variables such as usefulness, ease of use, social influence, facilitating condition, and community identification. Depending on the purpose for using Facebook, Facebook can have an educational outcome on communication, collaboration, and/or material and resource sharing (Mazman \& Usluel, 2010). 
The study sample consisted of 606 Facebook users who responded to an online survey. Most of the participants were from colleges and universities (425 undergraduate and 139 graduate students). As with previous studies, most of the participants were females ( $\mathrm{n}=309)$. However, 295 males participated, so this study had less of a discrepancy between the genders. After conducting a statistical analysis, the model turned out to be significant. The model may be able to explain (or attempt to describe) how Facebook is used in an educational setting (formal or informal). The study stated that students' satisfaction, motivation, or social presence on Facebook can affect their learning. The researchers stated that future studies should focus on refining this structural equation model (Mazman \& Usluel, 2010). There are some weaknesses with Mazman and Usluel's (2010) study. It is not known where these users came from; anyone in the world could have answered the survey if they knew English.

Mazer et al. (2007) examine the effects of faculty disclosure on student motivation, learning, and classroom climate. Mazer et al. (2007) surveyed a total of 133 undergraduate students, mostly freshmen, from a communications course at a large Midwestern university. Females made up the majority of the student sample, $\mathrm{n}=94$. There was a female teaching assistant that was teaching the class. She gave the researchers all of her photos so that they could manipulate the amount of self-disclosure, including biographical information, in posts for all three groups (high, medium, and low selfdisclosure). The students were told to come to a computer lab class at a specific time during the weekdays. They were randomly assigned to one of the groups and told to log on to Facebook. They were then shown a pseudonym of their instructor's name and told to find her on Facebook. There were told to browse her page and develop an impression 
and then answer a survey. The survey had three open-ended questions about their perceptions of their teacher's disclosure.

Mazer et al. (2007) found that students in the high disclosure group had higher levels of motivation, affective learning, and perceived a more positive classroom climate than those in the low self-disclosure group. There were no differences for the medium self-disclosure group in terms of motivation. However, there was a difference for affective learning and perception of a more positive classroom climate in the medium self-disclosure compared to the low group.

In the qualitative analysis, Mazer et al. (2007) found that students in the high and medium self-disclosure groups provided more positive comments of the teacher. For example, 38 of the high and 35 of medium disclosure group commented on the teacher's strength. Those in the low self-disclosure group could provide an accurate perception of their teacher. What is interesting is that a majority of the students who provided suggestions for teachers to use Facebook said to use Facebook as another method of communication, as source of examples and illustrations, and as a teaching technique. They also wanted to know more about the professors to connect with them more personally. As with Teclhaimanot and Hickman's study (2011), some of the students wanted their professor to respect the student's privacy and do not bring up issues they found on Facebook to the class.

One major concern of Mazer et al.'s (2007) study is their student representation. Most of the students are freshmen from an introductory communications class, so the results cannot be generalized to other class status. These students' majors are not known. 
The researchers did not address this in their discussion section. However, they addressed how the teacher's gender could have introduced some biases on the students.

Some studies have tried to implement social networking sites into the curriculum. Hung and Yuen (2010) surveyed 67 students enrolled in four face-to-face courses in two public universities in Taiwan. A social network site was created through Ning for each class; only members of that class had access to the site. The social networking sites were designed by the instructors and the researchers. The networking sites had a lot of elearning platform appeal and each student created their own profile.

Males represented $54 \%$ of the participants. Also, $76 \%$ of the students had experiences with Facebook, MySpace, and other social networking sties. A survey was done at the end of the semester. Hung and Yuen (2010) found that the students were in favor of using their social networking sites, especially for knowledge sharing, interactions, collaborations, and learning activities. Also, a majority of students (78\%) used the sites every week. The students also stated a strong sense of class community (Hung \& Yuen, 2010).

Hung and Yuen (2010) may have added biases to the study without realizing it. The students knew that they were being monitored for research purposes, which could have influenced their motivation and attitude toward the sites. Another concern is that they stated that at least $76 \%$ of the students viewed their class social networking site at least once a week; however, the researchers did not assess how often the participants visited other learning management systems, like Blackboard and Moodle. Therefore, the study does not provide an opportunity to examine if the students increased their study time using a platform. Another concern is possible cross-cultural differences that could 
complicate generalizability of the study results. The students in this study were from Taiwan, so generalizing the results cannot be made for United States college students or international students in U.S. colleges or universities (Creswell, 2010). None of these potential biases where addressed in the study.

Kabilan et al. (2010) surveyed 300 undergraduate students from the Universiti Sains, Malaysia. The researchers wanted to know the students' perspective of how Facebook was improving their English. There were 219 females and 81 males; $74 \%$ of the participants were fair to weak in terms of their English competency. Using descriptive statistics, it was found that students agreed that Facebook facilitated their English language learning; it also helped them building motivation, confidence, attitude toward learning, oral communication skills, and writing. The results of this study also cannot be generalized to American students. The researchers did not acknowledge any limitations to the study.

An exploratory study looked into how 128 undergraduate students used Facebook in an introductory organic chemistry class at Iowa State University (Schroeder \& Greenbowe, 2009). All students in the class were required to use WebCT. In addition, the researcher sent out an invite to all of the students in his class to join a Facebook group called Chemistry 231L. Participation in this group was optional. The students were told that it was a place for discussion between the students, the instructor, a teaching assistant, and a librarian. Students were told that they could share results of their homework assignments in the group to help the researcher find trends. The researcher approved of who joined the group and would not friend the students. By the end of the term only 52 students joined the group. 
Then Schroeder and Greenbowe (2009) compared the activity between WebCT and the Facebook group. Fifty-nine percent of the students did not join the Facebook group. The $41 \%$ that did joined the group were used to provide descriptive data. There were $400 \%$ more posts on the Facebook group, than on WebCT. Also, by the end of the first month, there were no further discussions on WebCT. The researchers noticed that as a deadline for an assignment was approaching, activity on the Facebook group would increase. Also, students were not asking their peers for answers, but instead were asking for assistance from the instructors.

Schroeder and Greenbowe (2009) did not ask the students why they chose the Facebook group instead of WebCT for discussion forums. Similarly, they did not compare the final grades between the Facebook users and the students who did not join the Facebook group. The researchers could have examined if the use of Facebook affected student attendance of the face-to-face portion of this blended course. The researchers could have developed a rubric to breakdown the students in the study between heavy discussion users, medium users, and low users. Another critique of the study was that demographical data (i.e., ethnicity, class year, and gender) was not collected.

Selwyn (2009) explored the content of Facebook profiles of all 909 undergraduate students in the School of Social Sciences at Claosville Univeristy, U.K. Seventy-five percent of the undergraduate students were females. Selwyn analyzed the profiles for 4 months to see the differences in profile contents in three semester periods: toward the end of a semester, during a semester break, and at the beginning a new semester. The researcher created a Facebook account, using his real name, and did not communicate 
with any of the students. The researcher primarily looked at the wall of the students' profiles.

After the wall posts analysis, five themes emerged: recounting and reflecting on their experience; exchange of practical information; exchange of academic information; engagement and disengagement; and nonsense (Selwyn, 2009). Most of the students would talk about their most recent experience involving the university. These encounters dealt with a range of aspects of university life: lectures, events, meetings, and places within the university. There was also a range of emotions, from enjoyment to pure anger towards the university.

One of the issues with this study would be that Facebook has changed a lot from what it used to be when the study was conducted. More privacy settings are available to Facebook users and new features (i.e., the timeline feature (Facebook, 2012) have been added that could either add or take away from students' educational experience.

McCarthy (2010) surveyed 120 students enrolled in a first year design course and did a pre-survey on their first lecture class. There were $54 \%$ males and $46 \%$ females. McCarthy assessed Facebook for a total of 6 weeks. A tutorial was given during the beginning of the class so that every student knew how to recognize Facebook's user interface. Then the students were assigned a task with a Facebook group, which was worth $15 \%$ of their final grade. The task required students to submit images and videos related to the gallery topic every 2 weeks and provide critiques on other students' submissions. There were 3 different galleries of the assessments. The students were graded on the relevance and quality of the submitted images and videos, the descriptions provided, and the quality and consistency of the discussions. The students completed a 
second survey at the end of the semester where they responded to questions about the effectiveness of the virtual and physical class and about their experiences.

The pre-survey results showed most students used Facebook to learn more about people they met in person and in class (McCarthy, 2010). The post-survey indicated the Facebook group was useful for student to deal with issues related to language barriers and introversion. Also, students' attitudes towards interactions with other students were mostly positive. The students reported the discussion on the Facebook group was supportive and provided a freedom of expression.

To summarize, most studies on curricular uses of Facebook have been conducted abroad (Hung \& Yuen, 2010; Kabilan et al., 2010; Koles and Nagy's, 2012; Quan-Haase \& Young, 2010; Selwyn, 2009). A model has been created to show how the adoption and purpose of Facebook affects student learning outcomes (Mazer et al., 2007). The level of openness from a professor may have an impact on how students can relate with professors and be open to learning new material (Hung \& Yuen, 2010; Schroeder \& Greenbowe, 2009). Students are on Facebook daily, and at times, sign on at various times on the same day; they are more likely to go on a group for their class and use it for discussions (Hung \& Yuen, 2010; Schroeder \& Greenbowe, 2009). Finally, students are more than likely to share their most recent experience about their class on their wall for others to see (Selwyn, 2009).

\section{Co-Curricular Activities}

Most students are involved in co-curricular activities in their college campuses. For example, Kirschner and Karpinsky (2010) reported that most of the participants in their study were involved in on average two or more clubs and organizations on campus. 
This section discusses relationship between Facebook and co-curricular activities in terms of student acclimation, engagement, and retention.

\section{Acclimation}

An Australian study looked at ways to blend virtual and physical learning environments to enhance students' experiences at the university (McCarthy, 2010). McCarthy surveyed 120 students enrolled in a first year design course and did a presurvey on their first lecture class. There were 54\% males and $46 \%$ females. McCarthy assessed the use of Facebook for a total of 6 weeks and did a comparison between international students and domestic students. The international students saw more benefits to usage of Facebook than the domestic students, In particular, Facebook helped them deal with issues of language, introversion, and cultural differences. McCarthy studied international students that acclimated to an Australian institution. Due to differences between Australian and American systems of higher education, the results should not be generalized to international students at an American institution.

A more recent study by Ryan, Margo, and Sharp (2011) provides some insight within a U.S. higher education institution. Using autoethnography, a qualitative research method, the researchers gathered data from first semester doctoral students enrolled in a research methods course in the College of Business at a large university in the Midwest. Of the 13 students who chose to be in the study, eight were international students; of those eight, six arrived to the U.S. for the first time at the beginning of the semester. The instructor created a Facebook group for the class. Each week a new cultural tip and a student tip were posted to the wall. Once the class ended, the students who had lived for less than 5 years in the U.S. were asked to provide narratives of their educational and 
cultural adaptations. The students were also asked to include if and how the Facebook group helped them adapt to living in the U.S.

Three themes that emerged on how Facebook can help in educational and cultural adaptations in higher education: enhancing knowledge exchange, alleviating apprehension, and enabling socialization and building communities (Ryan et al., 2011). The doctoral students were using Facebook to seek knowledge. They used the Facebook group's tips and discussions to supplement their knowledge and cultural adaptation. The Facebook group allowed people to ask questions that they would typically not ask in class. This allowed them to adjust to their Ph.D. program. At the same time, the Facebook group allowed the students to create a sense of community and build a relationship with the faculty.

Ryan et al. (2011) acknowledged that the sample was small and could not be generalized. Also, the sample consisted of first year Ph.D. candidates. Most of these students tend to be more mature and serious about their work and are more likely to use Facebook to further their career than undergraduates.

Unlike Ryan et al. (2011), the researcher in this study conducted face-to-face one on one interviews and included undergraduate students. To include diversity in the study, the researcher wanted to know the different perspectives of students who made up FIU.

\section{Student Engagement}

Facebook has been used to engage students in co-curricular activities. Valenzuela, Park, and Kee (2009) examined whether Facebook usage is related to individuals attitudes and behaviors towards their social capital. The researchers did a web-based survey at two large public universities in Texas, one university that serves predominantly 
undergraduates at a small town and another in a large metropolitan area. Two thousand six hundred students were randomly selected from both universities; $66.3 \%$ were females. They found that a greater intensity of Facebook usage was positively associated with the life satisfaction. The more the students increased their activity in Facebook, they more they engaged in civic participation. Only the increase of Facebook group, not individual, usage was associated with an increased political participation. Participation in school related Facebook groups showed similar results. Valenzuela et al. suggested that students who belonged to certain on-campus groups may be more willing to participate in cocurricular activities, especially if the group is related to their major or hobby.

Khan and Jarvenpaa (2010) examined how postings are placed on walls and how a group leader affects the group members' use of Facebook to coordinate events. The researchers analyzed 294 Facebook events. The events were digitally saved and then coded. Originally, the study had events from a Midwestern university in the U.S. However, the researchers expanded their sample with global networks. They collected trips and party events. The study had a total of 136 events from the university and 158 events from the global networks (Khan \& Jarvenpaa, 2010). It is important to know that Facebook today do not rely much on networks (Facebook, 2012).

Khan and Jarvenpaa (2010) found the Facebook groups had little interactions and most of the inquiries on the group pages were left unanswered. The average latency for response was 1.7 days, and if there were no immediate responses, then the post would more likely not have responses. The posts had three purposes: affective, cognitive, and behavioral. All three types were either negative or positive towards the group. The other 
finding was that if the group creator was involved in posts, there were significantly more responses from group members.

Although Khan and Javerpaa's (2010) finding of little interaction could be alarming, more research is needed because Facebook features related to interaction have changed a lot. Facebook groups now consist of more than just word posts. Facebook users can post pictures and videos and share links. The group interface has been redesigned. Khan and Javerpaa (2010) stated a limitation that Facebook did not notify users when someone responded to one of their posts. That is different today. Facebook will let one know that someone has posted something to the group and if one responded to a post, Facebook will update the user if other users have responded to the general post. Posts also show up on the newsfeed. A new feature that was not available in 2010 is that users that are part of a group can participate in a message room that multiple members can partake and have real time discussions (Facebook, 2012).

Junco (2012) looked into the relationship between the frequency of Facebook use and activities and its relationships to a student engagement scale, class preparedness, and other co-curricular activities. Junco surveyed 2368 students from a public Northeast university. The researcher asked students for their estimate amount of time spent on Facebook, the average amount of times they checked Facebook daily, and types of activities they did on Facebook.

From the 2368 students that participated in this study, 64\% were females and 36\% were males (Junco, 2012). The students spent on average 750.75 minutes per week preparing for class and 298.50 minutes per week participating in co-curricular activities. Also, the students spent on average 101.09 minutes on the Facebook on the day of the 
survey and 74.97 minutes on the site the day before; they checked Facebook 5.75 times on the day of the survey and 4.8 times the day before.

Junco (2012) also examined other variables that could affect student engagement. Junco defined student engagement as the amount of physical and psychological energy that student devote towards their curricular and co-curricular experiences. Junco used the National Survey of Student Engagement to measure student engagement and found that the amount of time on Facebook and overall Facebook activity were negative predictors of student engagement. Also, Junco found that two Facebook activities, RSVP'ing to events and playing games, were stronger predictors of student engagement.

Similar variables were found to affect student preparedness for class (Junco, 2012). The frequency of engaging in Facebook chat was a negative predictor of preparing for class. Junco was able to find positive correlations between student frequency of Facebook usage and co-curricular involvement. Three Facebook activities, playing games, checking up on friends, and posting pictures, were negative predictors of cocurricular activities. Three other Facebook activities, such as commenting on posts, creating or RSVP'ing to events, and viewing photography, were positive predictors of cocurricular activities. Junco acknowledged that his study did not find mechanisms of causation. Also, the sample did not represent students in all universities in the U.S., especially Florida International University.

\section{Retention}

Keeping students engaged in the university, either by curricular or co-curricular means, will allow them to be retained (Reiser \& Chickering, 1993). However, only one 
peer reviewed article (Morris, Reese, Beck, \& Mattis, 2010) has looked into the retention of students and its relationship with Facebook.

Morris et al. (2010) examined student social integration by assessing freshmen activity on Facebook. A total of 375 participants from a private Southwestern university were randomly selected from the Fall 2006 cohort. Of these, 62\% were female and 38\% were male. Eighty percent of them were Caucasian, eight percent African decent and five percent Hispanic. Eighty-four percent of students remained for the Fall 2007 term

The number of University Network Facebook friends, groups, wall posts, and photo albums was recorded (Morris, et al. 2010). No interactions outside of the university network were recorded. However, students were asked if they used Facebook primarily to connect with people at the university or with people not in the university.

The results showed that students that rated themselves higher in integration to the university were more likely to persist to the next year (Morris et al., 2010). Also, these persisters were more likely to have more Facebook friends and wall posts than the nonpersisters. What is interesting was that $70.3 \%$ of the presisters and only half on the nonpersisters used Facebook to connect with people at the university. Only Facebook friends, number of groups, and number of wall posts had a positive linear relationship.

There are some limitations to this study. Morris et al. (2010) recognized that the sample did not contain a representative sample of racially and ethnically diverse student population in the country. Also, it was a correlation study, so the study did not provide insights on how Facebook usage could cause retention. The study also did not provide much of descriptive information, for example, the types of posts the students made, the types of groups they joined, or the types of friend they had. 


\section{Summary}

Overall, few studies (e.g., Junco, 2012; Malesky Jr. \& Peters, 2012; Mazer et al., 2007; Teclhaimanot \& Hickman, 2011) have looked at Facebook and its impact on higher education. However, the few that do exist provide some insight into Facebook application in higher education and include three themes: Non-academic usage of Facebook and curricular and co-curricular activities.

There is no agreement on what students find inappropriate for faculty in their usage of any social networking website (Malesky Jr. \& Peters, 2012; Teclhaimanot \& Hickman, 2011). Students use Facebook frequently and at various time of the day (Koles \& Nagy, 2012; Hanson et al., 2011). Finally, students join Facebook because other students tell them about it and want to fit in; the students continue using Facebook as a way to try and entertain themselves or distract themselves, and in some sense to know what others are doing and stay connected with them (Ellison et al., 2007; Quan-Haase \& Young, 2010). What is interesting is that most of participants in these studies were female.

Most studies on effects of Facebook on curricular activities have been done abroad. A model has been created to show how the adoption and purpose of Facebook affects student learning outcomes (Mazer et al., 2007). The level of openness of a professor on Facebook may have an impact on how students can relate with professors and be open to learning new material. Students are on Facebook daily and sign on at various times on the same day; they are more likely to join a group for their class and use it for discussions (Hung \& Yuen, 2010; Schroeder \& Greenbowe, 2009). Finally, students 
are more than likely to share their most recent experience about their class on their wall for others to see (Selwyn, 2009).

Studies about co-curricular activities (e.g., McCarthy, 2010; Ryan et al., 2011) have shown Facebook has helped students, especially international students, acclimate to a new university. Several variables of Facebook usage could be predictors of student engagement (Junco, 2012). Students who comment on posts and create or edit events and have higher degree achieving parents are more like to be engaged on campus. However, predictability increases if the student is a male. 


\section{CHAPTER 3}

\section{METHOD}

This chapter describes the methodology of the research. It covers the research questions, the research design, the population and sampling procedures, the data gathering processes, and the researcher's role. Furthermore, it discusses the process used for data analysis and interpretation, as well as strategies used to attain trustworthiness.

\section{Research Questions}

Given the prominence of Facebook in young people's lives, more empirical studies are needed to determine whether Facebook simply offers an outlet for social interaction; it is important to understand whether Facebook also promotes students' academic studies. Based on interviews with students, this study answered three primary research questions: 1) To what extent do students use Facebook to further their studies? 2) In what ways do students use Facebook to further their studies? 3) What do students believe are the ways that Facebook can be used by colleges and universities to help students with their studies?

\section{Research Design}

The research design was qualitative interviewing. A semi-structured interview approach was used to collect data. With this type of approach the researcher may be able to obtain in-depth understanding of individual perspectives (Seidman, 2006). Given how little empirical evidence exists about the use of Facebook by students, such perspectives are important as a starting point for building a body of literature on social networking and higher education. Purposeful sampling was used to identify the participants. Purposeful sampling is important when considering the larger population of the site (Seidman, 2006). 
It allows the researcher to define the site and the sample to explain the experiences of the population.

\section{Research Setting}

The research was conducted between March and September 2012 at Florida International University (FIU). Located in Miami, Florida, FIU is a public research university with approximately 50000 students. FIU was used for convenience. Also because FIU is a large, urban, diverse university, which admits students at all levels of study, conducting this study at FIU gave the research an opportunity to obtain a diverse sample of participants.

\section{Population and Sample}

The population of this study was comprised of students from FIU from freshmen to doctoral candidates. To participate in this study, the students had to meet the following criteria: live on campus, commute to classes, and work on campus. Because little information exists about students' use of Facebook to further their studies, the sample sought students at all levels of study: first year students all the way to doctoral students and sought diversity in terms of race and ethnicity. Merriam (1998) states that "purposeful sampling is based on the assumption that the investigator wants to discover, understand, and gain insight and therefore must select a sample from which the most can be learned" (p. 61).

The primary method for sample selection involved the researcher asking faculty and staff at FIU if they could identify students that fit the criteria described next. Then the researcher approached students who came out of the residential halls, walked by the student union, and worked at front desk of the residential halls or at a fast food restaurant 
on campus. After a student was interviewed, the researcher asked if the student knew of another student who would be interested in participating in the study. A sample of nine students was identified.

\section{Description of Participants}

Of the nine students who were interviewed, two were graduate and seven undergraduate. Two were males and seven were females. Four were White, one of was of African descent, and four were of Hispanic origins. The ages ranged from 19 to 27. The sample consisted of juniors, seniors, masters', and doctoral students. Four students majored in elementary education; one was an accounting and finance major; one was in the masters in behavioral science program; one was in the doctoral biology program; one was an English major, and one was a psychology major. One student was from Dubai, one was from Colombia, another was from Brazil, and there was also a student from Nicaragua. Five students were born in the United States: one student in New York, one in Jacksonville and three in Miami. The participants were asked to create their own pseudonyms for anonymity purposes.

\section{Data Collection}

Data collection took place at FIU. Interviews served as the primary research method. An interview is defined as a purposeful conversation, usually between two people, that is directed by an individual who wants to get information from the other (Morgan, 1997; Seidman, 2006). Interviews are important for this study because interviews allowed the researcher to understand things that could not be directly observed, such as feelings, thoughts, intentions, and behaviors that took place in the past as people perceive them (Merriam, 2002; Morgan, 1997; Seidman, 2006). Interviews 
guided the researcher into understanding how students used Facebook for curricular and co-curricular purposes.

All interviews were face-to-face and participants indicated willingness to participate in the interview. Each interview lasted approximately 20-30 minutes; there was no compensation. At the start of the interviews, the researcher provided an introduction of who the researcher was and a detailed explanation of the project. The researcher introduced himself as an FIU student working on his master's thesis.

After the introduction, the researcher made it clear that continuing in the study entailed informed consent. Because the institutional review board granted exempt status, consent was obtained orally. Also, the researcher stated that he would not be looking at their Facebook profiles for information. An interview protocol (discussed later in this chapter) was used for guidance, but generally each interview proceeded on its own terms. No student were interviewed who did not consent to participating or to having the interview recorded. All of the participants choose to remain for the entre interview.

All interviews were audio recorded using a digital recorder. The researcher ensured that each participant understood the reasons for audio recording the interview sessions. The use of an audio recorder during interviews is instrumental in allowing a researcher to be an active listener (Bogdan \& Biklen, 2007). With the use of audio recording, the researcher eliminated any loss of data.

Interviews were held at the Modesto A. Maidique Campus and at the Biscayne Bay Campus. They were held during the day and in locations that were free from distractions and ensured privacy. 
The interview protocol used to guide this study included the following six questions:

(1) What are the ways in which you use Facebook?

(2) What are the ways in which you use Facebook academically?

(3) What are some of the ways your instructors and other professional have used Facebook to further your studies?

(4) Was it useful? If not, why was is it not useful?

(5) If given an opportunity to tell your professor, what would you tell him or her on how he or she should use Facebook to help you in your studies?

(6) If given an opportunity to tell an administrator, what would you tell him or her on how he or she should use Facebook to help you understand a department and its activities?

Whenever a student stated they never used Facebook for any academic purposes, the researcher would provide generic examples, such as "have you ever friended someone from your class?" Occasionally, the researcher would try to add other questions that were brought up in previous interviews, such as, "What are your thoughts about a professor friending you?" The purpose behind these questions was to get the students' perspectives and opinions if the students were in a similar situation as their prior peers.

At the end of the interviews, the researcher thanked the students for their participation and told that if they liked to see the thesis, they could email the researcher. The researcher asked the participants if they had any questions; none of the participants asked the researchers questions related to the study. If anything, the students were curious about the field of study of the researcher. 


\section{Data Analysis}

Analysis did not occur until all of the initial data was collected. This reduced imposing generalizations on participants further along the study (Seidman, 2006). Each interview was fully transcribed, including nonverbal clues, such as coughing and sighing; no unusual nonverbal cues were noted. After transcription, the data was coded. Coding allowed the researcher to make connections and categorize the data during data analysis. Codes are set of rules used to categorize data. By assigning some type of shorthand designation (e.g., words, letters, phrases, numbers, colors, or a combination thereof), data can be easily sorted and defined to be applicable towards the research purpose (Glense, 2006; Merriam, 1998). For example, the researcher would highlight several phrases and categorize them as examples of curricular and co-curricular activities. Then the author numbered each highlighted section from one to six. The numbers represented the question it belonged to.

Next, while reading the transcripts the second time, the researcher identified themes within each code. For instance, when the researcher interviewed Sofia, she discussed how a group of students used Facebook to cheat for a class. The researcher categorized this section as curricular, put question two next to it, and assigned it to the theme "cheating". The researcher then compiled a tally of the themes from all students to see whether they were relevant to the research topic. The researcher discovered that there were not enough data to convey themes. The author decided to use the categories and questions to discuss the results in chapter four. 


\section{Role of the Researcher}

The researcher, Frank Alexander Rojas, was the primary instrument for gathering and analyzing data. The researcher completed this thesis as a requirement for his Master's in Higher Education Administration at FIU. The researcher has had extensive use of Facebook since its inception in 2005. The researcher has seen the evolution of Facebook and how different people have used it over time. Also, the researcher was able to relate with students by using the Facebook language naturally, for instance by using words such as friending, posting, and messaging.

The researcher did his undergraduate degree at Florida State University (FSU). Coming from a different institution has allowed the researcher to have a learner perspective. FIU and FSU have different type of student population and undergraduate experience. The researcher was able to maintain a learner perspective because he was learning about the FIU undergraduate experience from his participants and comparing it with his FSU undergraduate experience.

The author may have introduced some biases. The author has had little experience with formal research, and this is the first time the researcher has done a qualitative study. To confront possible subjectivity biases, the researcher held a learner perspective and avoided conversations where the researcher would have to share his own experiences. If a student asked about the researcher's experiences with Facebook, the researcher would keep the answers short and generalized. The author would then ask a question relating to the study. During the data analysis phase, the researcher was intentional about asking himself how well what was being revealed reflected the perspectives the students held (Merriam, 1998; Seidman, 2006). 
Trustworthiness

Maintaining trustworthiness is critical in any qualitative research. The researcher received training through the Collaborative Institutional Training Initiative (CITI) in Responsible Conduct of Research and read extensively on qualitative research methods.

The researcher maintained a level of reflexivity to limit subjectivity to what was observed and heard, while thinking about the research process (Glesne, 2006). The researcher made sure that the conversations flowed and were not scripted. The only time the conversations ever sounded scripted were when the questions were asked. The researcher's effort to remain objective helped the researcher maintain the trustworthiness of the study. During the data analysis, extensive quotes were used to provide enough data for categories. In an effort to address validity, the use of extensive rich quotes may allow the reader to interpret the students' perspective and may provide an element of shared experiences. Also, the results become more realistic with more detailed information provided (Creswell, 2009).

\section{Chapter Summary}

The researcher interviewed nine students at Florida International University to examine the student perspective of how they use Facebook to further their studies. The primary instrument for gathering data was 20 minute face-to-face and one-on-one interviews. The data collected was transcribed, coded, and analyzed. The next chapter discusses the results from the data analysis of the interviews. 


\section{CHAPTER 4}

\section{RESULTS}

This chapter provides the findings of the interviews. The chapter starts with a student profiles section. Next, the study results are presented in relation to the interview questions:

(1) What are the ways in which you use Facebook?

(2) What are the ways in which you use Facebook academically?

(3) What are some of the ways your instructors and other professionals have used Facebook to further your studies?

(4) Was it useful? If not, why was is it not useful?

(5) If given an opportunity to tell your professor, what would you tell him or her on how he or she should use Facebook to help you in your studies?

(6) If given an opportunity to tell an administrator, what would you tell him or her on how he or she should use Facebook to help you understand a department and its activities?

The exception is that questions 2, 3 and 4 are combined in their own section.

\section{Student Profiles}

Itachi was the first male interviewed in the study. He is a White male. At the time of the interview, he was of the age of 21 and an international student from Dubai. Itachi was majoring in English literature and was Senior. Also, Itachi worked at the Biscayne Bay Campus. Itachi stated he used Facebook to keep in contact with his family and close friends. He had a serious tone at the time of the study and was not afraid to tell the researcher his point of view. 
Sofia was a 19 year old female, of Hispanic origins, and a junior in accounting. Sofia was born in Cali, Colombia, and came to the United States when she was a child. Sofia had used Facebook for curricular and co-curricular activities. At the time of the interview, Sofia did not sound confident in what she was telling the researcher. However, Sofia did respond to all of the questions and clarified some answers. Sofia was highly involved in a sorority, along with dance marathon and other campus wide philanthropic events. At the time of the interview, Sofia held a managerial position at a videogame retail store.

Nancy was a 22 year old female, of African descent, and was a senior in early childhood education. She said she considered herself as a causal Facebook user. Nancy had been open to using Facebook for different purposes. Nancy grew up in Miami and worked at the Modesto Malidique Campus at the time of the interview.

Cassandra was a junior in psychology. She was a 21 year old female and saw Facebook as a way to communicate with her family that lived outside of Miami. During the interview, Cassandra showed a great importance to keeping ties with her family. Cassandra was originally from Jacksonville, Florida. One of her hobbies was cars. She was well versed in the world of cars. One of her Facebook usages was that she tried to network with other individuals that shared her car hobby. At the time of the study, she was rebuilding an engine on a car she owned.

Juliana was a 21 year old female senior in elementary education. She was originally from Brazil. However, when the researcher asked her about her ethnic background, she was unsure. She brought up the fact that Brazil is not a Hispanic country. Yet, she did not share a lot of cultural similarities with White Americans. She 
stated that her mother always told her to put down "White" on government forms. She classified herself White; however, she was still uneasy saying it to the researcher.

Amy was a 23 year old Hispanic female and a junior in elementary education. She was originally from New York City and used Facebook to keep in contact with her family in Puerto Rico and New York City. Amy stated that she frequently used Facebook for curricular purposes. While being interviewed, Amy expressed her sincere interest in helping children. She was running her own business and working at a local school in Miami-Dade County.

Denis was a 20 year old Hispanic female. She was also a junior in elementary education. She had just started her upper level division courses in elementary education. Amarylis was a 23 year old Hispanic female student. She was in her first year of her Master's program in behavioral analysis. She was born and raised in Nicaragua, her father was from Nicaragua and her mother was from Puerto Rico. Amarilys grew up in a high socio-economic status household. She went to American schools in Nicaragua; this explains why she did not have an accent when speaking English. Amarilys went to a small private catholic university located in the Northeast of the U.S. Amarilys wished to work with autistic children when she graduates with her master's.

Finally, there was Jamos. Jamos was a first year biology doctoral candidate. He was a 27 year old White male who had already completed a master's in two European higher education institutions. It was apparent that Jamos was serious about his education. He liked to seek for information. He stated how he used Facebook to seek out information on his field and to learn about a person when meeting him or her for the first time. 
Non-Academic Usage by Students

Six students stated that they used Facebook to keep in touch with their family members, especially family members that lived abroad. Specifically, Itachi said, I only use Facebook for personal use. I use Facebook to communicate with families and friends. Close families like my mother, brother, uncle, aunt, and grandfather from Dubai.

Itachi talked about his family immediately when asked the question, "Describe the ways in which you use Facebook." Itachi still cared about his family, more so because he was in the US. He felt that he still was in contact with them. Itachi specified the family members he kept in contact on Facebook. Amy stated that she used to keep in contact with her family members in New York. Juliana stated that she was of Brazilian decent and that she had family that still lived there. Sofia used Facebook to keep in contact with her cousins in Colombia. Cassandra said she contacted both friends and family at the same time:

I guess Facebook helps you feel you are still part of your life when you are away. You can still look at their pictures, look at what they are doing, and see your younger siblings or younger cousins growing up. My cousins are really young and changing all the time. My aunts are taking pictures and saying what they are doing. I can pretty much watch them grow on Facebook.

Cassandra offered details of how she used Facebook to keep in contact with her family. Specifically, she missed seeing her younger cousins, so she kept contact with them through Facebook where their pictures were continuously updated.

Another non-academic usage of Facebook by the students was to keep in contact with friends. Eight students stated that they kept in contact with friends over on Facebook, especially with friends that lived in another town, city, and country. For example, Amy still had a lot of friends in New York and she preferred to use Facebook to 
communicate with them instead of calling them. Amarylis immediately said "friends" when asked to describe the ways in which you use Facebook. She said, "I like to be personally connected with my friends who are overseas." Cassandra stated,

I get to see people who I haven't talked to in a long time. I can see what they are doing. Also, I can see people who I use to hang out with all the time. I can keep up to date with them and contact them. Also, I use Facebook as a way of networking with people that I meet. I want to keep in touch with important individuals or get together and work on something. If I meet someone that have something in common, I use Facebook to work together.

Not only did Cassandra care about her family, but she also kept in touch with people with whom she had some type of connection. Cassandra also stated that she also used Facebook to network with people.

Entertainment was another reason for using Facebook. Cassandra and Amarylis said that they sometimes logged on to view other people's pictures. Specifically, Amarylis said that she used Facebook when she was bored and viewed her friends' pictures. Cassandra said,

I use it for my car hobby. For people who I don't actually know. Talking with them in social groups of cars, which is my hobby, that way we can share ideas, make meetings, plan events, stuff like that.

Cassandra stated details of how she used Facebook for her car hobby. She used Facebook to organize with other people that shared the same hobby and interchange their ideas and opinions about cars; she used Facebook as a start to what she wanted to know or do about cars.

Most of the students stated that they used Facebook to communicate and continue relationship with their friends and family, especially with those who lived far away. Also, many used Facebook to entertain themselves. 
Academic Usage by Students

When asked to describe the ways in which students used Facebook academically, most said that they did not use it academically, but as the interview progressed, some of the students would recall instances when they used Facebook for their studies. The most frequently stated reason for using Facebook was collaboration. Eight of the nine students stated an instance of using Facebook to work together with other students. For example, Sofia said she had used Facebook to be part of groups for classes. She would post questions to the group. She had been in various groups that were set up by fellow students. She had been in two groups where they were set up by professors. Nancy, Cassandra, Amarilys, Juliana, and Denis also used Facebook groups to help them with their assignments. Nancy provided a good description of how she used the groups for academic purposes:

One of my classmates did not have a cellphone. She said to add her on Facebook. We would instant message each other for homework assignments, information, meeting, and general information about the chapters we are reading. Also, on group assignments and when we are working on a PowerPoint, we would send each other our portion of the work on Facebook. Instant messaging worked because everyone would response right away.

Using some of the features provided by Facebook, such as instant messaging, Nancy would stay in communication with her fellow classmates who did not have a cell phone.

Nancy even stated an example of how she kept in contact with a professor:

With my professor, it is more so, you know keeping in contact, asking questions such as 'are you offering classes next semester?' That is how I used Facebook with her since I also talk with her in person. 
Nancy stated that she would seek informal conversations with one of her professors. The conversations were mostly related on Nancy's curricular aims.

Juliana said, "I have a lot of friends from my classes. I ask them for help." Amy said,

Once in a blue moon I ask my friend for help or advice on an assignment. Sometimes I put it up on my status and ask what should I do, can somebody help me, and has anyone taken this course before?

Amy described the ways she used Facebook to seek help in her studies. Amy then provided some of the methods she used to seek for help. For example, she used the status update feature of Facebook to advertise her question to her friends. When Amy was asked if friends responded to her questions, she said,

Yes, I have a lot of friends who are in my program. I am also part of the elementary education program page. They sometimes help me there.

Amy indicated that people that were friends with her were helping her with assignments.

It is not known what kind of help she was receiving.

Denis said,

Sometimes I am in a group project with people, like in education class. We form a group on Facebook and that is how we communicate with each other. We like talk about our assignments and what we have to do. What we each have to do for our project.

Denis provided a clearer description of how she used Facebook for her curricular activities. She formed a Facebook group with her classmates when they had a group project, assigned roles, and provided updates in the Facebook group so that everyone could see it.

The two males in the study stated that they had not used Facebook academically. Jamos said he did use Facebook indirectly for academic purposes: 
Academically, is not related to classwork or my research in particular, but I use Facebook to keep up with current news of biology by the links my friends post. My friends usually post science articles, new experiments, and latest research. That is the quickest way I hear about it. My friends are very nerdy so at least once a day I do this. I rarely used groups. Personally I think it is a conflict of interest with professors as friends. The way I use it works out for me.

Jamos used Facebook towards academic purposes by seeking out articles or news on the current trends, studies, and works done in his field of study. He was increasing his knowledge on the subject matter and could share this knowledge in class. Also, Jamos stated that his friends on Facebook were academically inclined, so he surrounded himself with other individuals that shared his prioritization of academics.

Jamos answer was surprising. One would have thought that Jamos would have been opened to the idea of using Facebook for classes because he was a first year doctoral student. However, his prior experiences had affected his view on using Facebook for curricular purposes.

Sofia provided an interesting example of using Facebook for curricular purposes.

She stated an instance of cheating:

I have heard a lot of people use it just to get answers. If people needed answers for homework or they had an online tests they get answers from the group. I've heard people complaining about it especially because a class had a Facebook group and there were like 300 people in the Facebook group. The professor found out and wanted to get everyone in trouble, but he couldn't because it would have been the whole class. So then he decided to get the ones that created the group in trouble. I don't know what else happened but yeah that's what I heard that he was like really mad because of that.

Sofia also said,

People were sharing answers for the homework and it was online homework. I guess somebody in the group talked to the professor and showed him the group. There were like two or three people that created the group and he wanted to get them in trouble, on probation or something with the university. 
Both of the preceding quotes by Sofia provide details of how the cheating was done. A majority an economic class was in a Facebook group, which shared all of the answers to the online assignments. The professor found out about the group and wanted to start academic misconduct procedure for the entire class. However, the professor decided to pursue only the individuals that created the group.

Five of the students said that they had used Facebook for academic purposes. The students primarily used it to collaborate. However, Sofia stated that she knew of people that had used Facebook to cheat in a class. Seven of the students did not like to use Facebook as a tool for curricular activities. Nancy and Sofia like Facebook as a tool for curricular activities and had begun to use it for their classes.

\section{Professor Involvement}

The students were asked if given an opportunity to tell their professor, what they would tell him or her on how he or she should use Facebook to help them in their studies. Three students said they would not mention anything to their professors. Itachi said,

I wouldn't because I've chosen to keep Facebook secretive not for any other purposes. Just because I use Facebook to communicate with friends or family and I don't involve anything political or school related material.

Similarly, Jamos said,

I would not tell them to use it. Do not think it is needed. If it was going to happen anyways I will still partake in it. However, I will only read posts and not contribute to the group.

Itachi said he would not use Facebook for any academic related material. Itachi had already used Facebook to keep in touch with his close friends and family and wanted to keep his personal, work, and school related roles separate form one another. Itachi's 
response could mean that depending on the students' purpose for using Facebook, they may or may not be willing to use Facebook for their studies.

Jamos would not suggest to his professor to use Facebook for classes. Jamos did say that if the professor were to use Facebook in his class, then Jamos would use it, but not be engaged in it. Jamos' response is interesting in that he did not want Facebook to be an active part of the curriculum. However, he liked using Facebook indirectly to help him learn new trends and findings in his field of study. Jamos stated that in his regular usage of Facebook he checked to see what kind of articles his friends had posted. These articles were either news related or they were about studies in biology.

Other students thought it was good to tell a professor how to use Facebook for their studies. Sofia said,

I would just tell them to make a Facebook group for the class. It is actually really helpful because I don't use it for cheating or anything like that but sometimes, you know, you don't go to class and you need some information that the professor gave out, but you don't know anyone in class. But being a group you can see what happened in class or people have the same questions as you. You can get an answer and get help with the homework and study so actually really helpful.

Sofia would have appreciated if a professor made a Facebook group for a class. She thought the group could be beneficial to shy students because they would feel less anxiety when asking questions or help for an assignment. She specifically stated that she would not want to use Facebook for cheating. Sofia used Facebook when she would miss a class to see if anyone would tell her what she missed. This could potentially lead to students to rationalizing not coming to class.

Juliana said, “create groups for classes. It can help us get connected and I can just be in group and say 'Hey what's up did I miss anything in class?' it will make it easier on 
us." If Facebook were to be used for curricular purposes, Juliana would use it to get to know her fellow classmates. Although she said a Facebook groupf or a class could give her an excuse to miss her classes. She said she would ask her classmates in the group for the class material she had missed.

Cassandra said,

Well, in psychology it can be used for studies about Facebook. There is a lot to be studied in that area. I would just give projects about Facebook. If I wanted to say something to the professor I guess they can send out messages on Facebook. Make a group on Facebook. But I haven't known any professors to do that. I do not know how many people would actually do it. I know some people that are antiFacebook and people who do not get on Facebook all the time. If the professor made an assignment that was on Facebook and you had to go to it, then that might make that student feel stereotyped or offended because they are not on Facebook.

Cassandra said that professors in the psychology department could make research assignments based on Facebook. They could send out Facebook messages through a Facebook group. However, she said that she did not know a professor to do this and that such use of Facebook for a class could alienate some students who were not on Facebook. Amarylis stated a different opinion:

I feel that they could use it. Given that so many people use Facebook, maybe they could set up a their own Facebook page and maybe they can post their office hours or the telephone numbers or like just set up like a webpage for people who are in their class. I guess considering student spent so much time there, I guess they can benefit from it since you can multitask. They can set up office hours on Facebook, they include the time and location. They can post their research and interesting stuff that their conducting and the students can provide their input and learn from that. A professor can also have office hours on Facebook and it can help you as a student to learn fast on how you can contribute.

Amarylis said that a professor could provide information, which they would typically post on their office doors or through Blackboard, on a Facebook page. She explained that because a lot of students were already on Facebook, they could be more 
willing to check their groups and participate in group discussions. Using another medium, like Blackboard, would require students to do more work. It is important to keep in mind that she was a graduate student. Most graduate students would like to know more about their professors so that they could get a better understanding of their program and field of study. It is not surprising that Amarylis would like to know more about her professors, compared to an undergraduate who may or may not have different priorities and distractions.

Nancy found the ways in which her professors used Facebook effective. In an ESOL learning research class, the professor had assignments and events on a Facebook group where students discussed their opinions and reached out to other students. Nancy also said that students used the group till the end of the semester.

Amarlys stated that she would find it appropriate for a professor to make a Facebook group to have discussions and know more about the professor. Nancy already had one of her professor as a friend and would appreciate for professors to create groups for classes. Only one student, Amarlys, said that they would find it appropriate for a professor to use Facebook for curricular purposes. Five students gave examples of what they would tell their professors, but they would not want their professors to be heavily involved in Facebook. Three said they would not want to tell their professors any suggestions on using Facebook for curricular purposes.

Administrative Involvement

The students were asked if given an opportunity to tell an administrator how the administrator should use Facebook to help the student understand a department and its activities. Seven students in the study said that groups would be beneficial for 
administrator to use for their departments. Sofia said administrators should use Facebook for their department as another means of communications that students also use on a daily bases. Sofia said, "I have a lot of groups for my organizations I am in and also for FIU." Sofia uses Facebook to communicate with individuals that are part of her campus organizations, including her sorority. Sofia said,

More Facebook groups is helpful, just not for cheating. Being in a group forms friendships and it is easy to talk to others, including administrators.

Sofia stated she would use it to spread news about current events at FIU to other students or within her sorority.

Juliana said, "I am in the elementary education group. But I do not do anything with [the group]." Juliana was in the College of Education's elementary education group; however, she was not active in the group.

Nancy stated that administrators

Should include the policies for the department in a group. It is a business outlet. I feel like it is the young thing to do. There can be fun ways to address issues. If the administrators constantly updates statuses, then they can receive feedbacks.

Both Sofia and Nancy used Facebook to communicate with their on-campus organizations. Nancy described administrators' use of Facebook by comparing it to a customer service desk at a retail store. The administrator would be present to address students concerns relating to the department. At the same time, the administrator would be able to address the department's goals by using the Facebook features to attract students and engage them in discussions through posts. Nancy seemed to want the administrator to take a constant active role in the group with the students. 
Amy, Denise, and Juliana did not give much information to this question. They stated that administrators should post updates and due dates for the department requirements. Amarylis said something similar:

Administrators should use Facebook to advertise their activities and promote the Facebook groups on campus. Almost all of the students use Facebook. It is worth taking advantage of that.

These responses by Amarylis, Amy, Denise, and Juliana indicated that it was appropriate for administrators to use Facebook.

Jamos was excited to provide his answer. He said,

Hmm that's good! I like how you worded this question. The Marine ecology department, where I did my Masters, had a Facebook group where I could like them and be informed of seminars. It was a great way to advertise seminars and events. I have not experienced that here at FIU. This was in Portugal.

Jamos response indicated that he found it appropriate for administrators to be on Facebook and use it for their departments to help students due to his a positive prior experiences. This is opposite on his view of faculty: He thought it was inappropriate for faculty to use Facebook for curricular activities because of his prior experiences with professors playing favoritism.

Most of the students liked the idea of administrators using Facebook to further enhance the students' co-curricular activities. Students would appreciate to be kept up to date with on-campus activities. The students said that they received information through Facebook groups that allowed them to attend on-campus events or participate in group discussions. 


\section{Summary of the Chapter}

Chapter four was structured based on the interview questions and provided results around student usage, academic usage, professor involvement, and administrator involvement. Most of the students stated that they used Facebook to communicate with their friends and family. The students that lived far away from their family used Facebook as a tool to stay in communication with them. Also, students used it to continue their relationship with their friends. Seven students did not use Facebook as a tool for curricular purposes. Five students used Facebook for their studies, but only two considered it useful to advance their studies. The primary curricular usage of Facebook was collaboration.

Only one student said that they would find it appropriate for a professor to use Facebook for curricular purposes. Five students gave examples of what they would tell their professors, but they said that they did not want their professors to be heavily involved in Facebook. Three said they would not want to tell their professors any suggestions on using Facebook for curricular purposes.

Most of the students liked the idea of administrators using Facebook to further enhance students' co-curricular activities by providing update on on-campus activities. The students said that they received information through Facebook groups that allowed them to attend on-campus events or participate in group discussions. 


\section{CHAPTER 5}

\section{DISCUSSIONS AND CONCLUSIONS}

The purpose of this thesis was to study students' perspective on their use of Facebook to further their studies. Its results provide a way of thinking about Facebook and its relationship to higher education. This chapter provides a discussion and interpretation of the key findings that answer the three research questions: 1) To what extent do students use Facebook to further their studies? 2) In what ways do students use Facebook to further their studies? 3) What do students believe are the ways that Facebook can be used by colleges and universities to help students with their studies? The chapter ends with a discussion on the limitations, recommendations for future research and for instruction and practice.

\section{Summary}

The study contains five chapters. Chapter 2 provides a review of the literature. No empirical literature discusses student perspectives on their usage of Facebook for curricular and co-curricular purposes. Therefore, emprical studies on student usage of Facebook in general were reviewed and presented in three sections: (a) non-academic uses,(b) curricular activities, and (c) co-curricular activities.

Chapter 3 described the phenomenological framework and methods of data collection, analysis, and management. Six questions provided the basis of the interviews:

(1) What are the ways in which you use Facebook.

(2) What are the ways in which you use Facebook academically.

(3) What are some of the ways your instructors and other professional have used Facebook to further your studies? 
(4) Was it useful? If not, why was is it not useful?

(5) If given an opportunity to tell your professor, what would you tell him or her on how he or she should use Facebook to help you in your studies?

(6) If given an opportunity to tell an administrator, what would you tell him or her on how he or she should use Facebook to help you understand a department and its activities?

Chapter 4 presented the findings. Nine students were interviewed. Most of the students used Facebook for personal reasons, such as keeping in contact with family and friends. Some of the students did not want to use Facebook to further their studies, while others wanted to use it for curricular and co-curricular purposes. The students that wanted faculty and administrators to use Facebook said that they would want them to create groups for their classes. Some of the students stated it would provide an opportunity for the professors to build relationships with their students.

\section{Discussion of Key Findings}

Most students did not want to use Facebook in their studies. Students said that they felt uncomfortable having a professor monitoring their discussions. Students that used Facebook for their studies provided some examples. Finally, students preferred that administrators use Facebook to advertise their departments and events. This section focuses on answering the three research questions.

\section{The Extent of Student Use of Facebook for Their Studies}

Students did not want to use Facebook in their studies. Most of the students used Facebook to communicate primarily with people they already knew, such family members or friends. This was consistent with other studies (e.g., Ellison et al., 2007; 
Quan-Haase \& Young, 2010) that have found students like to look at their friends' comments, pictures, and posts to compare them their friends' lives with their own. Also similarly to Ellison et al. (2007) and Quan-Haase \& Young (2010), this finding was true for students regardless of their academic standing.

Five students used Facebook for their studies, but only two frequently. Consistent with Mazman and Usluel (2010) and McCarthy (2010), students who saw Facebook as a tool to enhance their studies used it for that purpose. Students used Facebook to get a hold of or get to know classmates better. Some of the students used it to help facilitate group communication and to get help with their assignments or ideas for projects. It is important to note that only two students used Facebook for their studies intentionally and three other students used Facebook for their studies unintentionally and did not want Facebook to be implemented in their classes.

Overall, students did not use Facebook for curricular purposes extensively. Consistent with Quan-Haase and Young (2010) and Kolek and Saunders (2008), students used Facebook for their own personal gratification of keeping up with friends, family, and hobbies. Students preferred to keep their school life out of Facebook and most of the students that used Facebook, at one point, for their studies; however, they did not use Facebook primarily for academic purposes.

Students were more open to use Facebook for co-curricular purposes. Students who were in on-campus organizations used it to communicate with their members and organize events. The students stated that using Facebook as a medium of communication had positive results: More members and other invitees would participate in the advertised events. It is important to note that most students did not discuss how they used Facebook 
for co-curricular activities. All but two participants discussed co-curricular activities only in response to question six. It would seem as if the students did not associate cocurricular activities with their learning.

\section{Ways Students Use Facebook for Their Studies}

The students who used Facebook for curricular purposes used the group feature to communicate with other students in their classes. The students created a Facebook group and invite each other to join the group. Also, some of the students would post on their walls questions related to their assignments and their friends would provide them help. This is similar to how the students in Schroeder and Greenbowe's (2009) study used Facebook for a discussion tool for a chemistry class. However, in Schroeder and Greenbowe's (2009) study the discussion group was created by the instructor to give students an opportunity to talk to the instructor, teaching assistant, and a librarian about class assignments. In this study, it was students who created the groups to exchange basic knowledge related to their classes.

All but one students did not feel comfortable being friends with a professor. Only one student stated that she was friends with a professor. This is consistent with Malesky Jr and Peters' (2012) study where all students, especially female, did not feel comfortable being friends with their professors.

Students used Facebook for co-curricular purposes in different ways. Three students joined groups that helped them communicate with other members that belonged to their on-campus organizations. They posted events and reminders about upcoming events. It also allowed the students to friend each other. 
Three students joined a department's Facebook group page. However, only one of them was actively engaged in the group. The student stated that she would ask questions to the group and get a response from several people. Another student said that in his prior institution he was in a group, headed by his department, and would look for dates and campus events related to his field of study.

\section{Students' Beliefs How Facebook Can be Used to Further Studies}

Seven of the nine students did not believe Facebook should be used by the university to help them in their curricular activities. Four students specifically said that they wanted to keep Facebook for their personal life only. Three students believed that Facebook could help them in their studies. These students wanted their professor to create a Facebook group so that the class could join and participate in discussions.

Two of the students said that Facebook groups would help them ease with transition to a program or a class, get to know other students in their classes and in the program, and ask questions related to classes or programs. This is similar to results of Ryan et al. (2011). Doctoral students in a research class were in a Facebook group, created by the instructor, where cultural and student tips were provided every week. The students said it helped them acclimate to their program.

Seven of the nine students agreed that administrators should use Facebook to help the students further their co-curricular activities. They wanted administrative departments to make Facebook groups to provide such information as office hours, upcoming events, deadline reminders, and staff directory. One student suggested that departments should also include department policy information. 
Students thought that administrators should use Facebook to provide information on co-curricular activities because students already used Facebook. Only two students did not see any value of telling an administrator of how to use Facebook to promote cocurricular activities. One student said that an email was enough for him to know about a department. Another student said it would add extra work for an administrator.

\section{Limitations}

This study has several limitations. Only two male students agreed to participate in the study, so responses from male and female participants could not be compared. Also, not enough students were recruited to see if there was a difference between undergraduate and graduates students. Another limitation was that the researcher may have used terms, for example the word co-curricular, that the student did not understand. When the researcher used the word co-curricular, some students seemed confused and the researcher had to re-word the question. Due to a limited experience with interviewing, the researcher asked only the six guiding questions and did not ask additional questions, which could have provided more insight. For example, one student gave the researcher an instance of using Facebook for cheating. Three students formed a Facebook group so that everyone that joined could share their answers from the online assignments and quizzes. At the time of the study, the researcher thought that other students would not have wanted to share their experiences with cheating using Facebook, so the researcher did not press the issue to other students.

\section{Recommendations for Future Research}

In the future, researchers could look at the relationship between student academic priorities, personalities, and perspectives on their usage of Facebook to enhance 
their curricular and co-curricular learning outcomes. Other studies could explore characteristic of studnets who use Facebook for their curricular and co-curricular activities. Also, it would be great to do several studies in each of the colleges available at a university to see if student use of Facebook depends on their discipline. It would also be interesting to conduct a similar study using mixed methods or quantitative methods. This study revealed some students use Facebook to cheat for classes, so another study could examine how and how often students use Facebook for cheating. The differences between collaboration and cheating on Facebook have not been examined, so when using Facebook for classes, students might violate ethical rules of the university. Researchers could explore how students could use Facebook for collaborative purposes without cheating. Another research could examine in depth how students use Facebook for cocurricular activities. This study found that students were more than willing to use Facebook for co-curricular activities. However, the researcher wondered if the students knew that co-curricular activities help them with their learning.

\section{Recommendations for Instruction and Practice}

The results on this study can be used for instruction and practice in higher education. One recommendation is not to use Facebook for classes at all. The majority of the students in the study stated they would not want Facebook to be used for curricular purposes. If the majority of other students in a university share the same sentiments, then the professor should not use it at all for their class. However, professor can use Facebook indirectly in their class. Depending on the class, a professor can use Facebook to illustrate some course topics. For instance, in a psychology class, a professor can provide blurred profiles of other students in maladaptive behaviors. Also, in a business ethics class a 
professor can provide examples of how employers judge a candidate based on the moral and ethical decisions posted on a profile. As long as the professor does not make Facebook a primary tool of teaching, the students would be fine.

Using Facebook in a co-curricular setting would be viewed appropriate by most students. Administrators should use Facebook to promote programs and departments that are available to students. Having group discussions based on an upcoming event would be beneficial in engaging students before an event. Also, a department can do weekly giveaways where students would have to answers questions, show up to an event, or talk to someone in a department to be able to receive the gifts.

Departments should not use Facebook to have direct contacts with students. For instance, an administrator should not use Facebook to have instant messages with students. Students do not find it appropriate to be contacted on Facebook through instant messaging by their instructors. They might feel the same way when contacted by an administrator.

\section{Conclusion}

By interviewing nine students, from freshmen to doctoral candidates, this study examined their perspective on how Facebook could be used for their studies. This study was important due to limited amount of empirical literature on how Facebook impacts higher education. This study was conducted at Florida International University between the months of May and September, 2012. There were three major findings in this study: (a) students use Facebook to keep in contact with their friends and family, (b) students do not want to use Facebook for curricular purposes, especially if a professor is in a 
Facebook group, and finally, (c) students do like to use Facebook for co-curricular purposes, especially if administrators use the group feature.

By the time this chapter was written, Facebook had grown to one billion users, which is approximately $14 \%$ of the world population of seven billion. Most students in higher education have a Facebook account (Khan \& Jarvenpaa, 2010). If Facebook popularity continues, its impact on higher education will continue as well. Therefore, more studies around Facebook and different aspects of higher education are warranted. 


\section{REFERENCES}

Ajjan, H., \& Hartshorne, R. (2008). Investigating faculty decisions to adopt web 2.0 technologies: Theory and empirical tests. The Internet and Higher Education, 11(2), 71-80. doi: 10.1016/j.iheduc.2008.05.002

Bogdan, R. C., \& Biklen, S. K. (2007). Qualitative research for education: An introduction to theories and methods (5th ed.). New York, NY. Pearson Education Inc.

Boyd, D. M., \& Ellison, N. B. (2007). Social network sites: Definition, history, and scholarship. Journal of Computer-Mediated Communication, 13(1), 210-230. doi:10.1111/j.1083-6101.2007.00393.x

Bowers-Campbell, J. (2008; 2008). Cyber "pokes": Motivational antidote for developmental college readers. Journal of College Reading and Learning, 39(1), 74-87.

Chickering, A. W., \& Reisser, L. (1993). Education and identity (2 ${ }^{\text {nd }}$ ed.). San Francisco, CA: Jossey-Bass.

Clipson, T. W., Wilson, S. A., \& DuFrene, D. D. (2012). The social networking arena: battle of the sexes. Business Communication Quarterly, 75(1). 64-67. doi: $10.1177 / 1080569911423961$

Creswell, J. W. (2009). Research design: qualitative, quantitative, and mixed methods approaches $\left(3^{\text {rd }}\right.$ ed.). Thousand Oaks, CA: Sage.

David, J. C. (2010). New friend request: the relationship between Web 2.0 and Higher Education. Journal of Student Affairs, 19 37-43.

Dawson, S. (2010). "Seeing" the learning community: An exploration of the development of a resource for monitoring online student networking. British Journal of Educational Technology, 41(5), 736-736-752. doi: 10.1111/j.14678535.2009.00970.x

Ellison, N., Steinfield, C., \& Lampe, C. (2007). The benefits of Facebook "friends": Exploring the relationship between college students' use of online social networks and social capital. Journal of Computer-Mediated Communication, 12(3). 210230. doi: 10.1111/j.1083-6101.2007.00393.x

Elster, D. (2010). Learning communities in teacher education: The impact of Ecompetence. International Journal of Science Education, 32(16), 2185-2216. Retrieved from http://search.proquest.com/docview/815957527?accountid=10901 
Facebook. (2012). www.Facebook.com

Glense, C. (2006). Becoming qualitative researcher: An introduction. Boston, MA: Pearson.

Hanson, T. L., Drumheller, K., Mallard, J., McKee, C., \& Schlegel, P. (2011). Cell phones, text messaging, and Facebook: Competing time demands of today's college students. College Teaching, 59(1), 23-30.

Hung, H., \& Yuen, S. C. (2010). Educational use of social networking technology in higher education. Teaching in Higher Education, 15(6), 703-714.

Joly, K. (2007). Facebook, MySpace, and co.: IHEs ponder whether or not to embrace social networking sites. University Business, 10(4), 71-72

Judd, T., \& Kennedy, G. (2010). A five-year study of on-campus internet use by undergraduate biomedical students. Computers \& Education, 55(4), 1564-1571. doi: $10.1016 /$ j.compedu.2010.06.022

Junco, R., Merson, D., \& Salter, D. W. (2010). The effect of gender, ethnicity, and income on college students' use of communication technologies. CyberPsychology, Behavior, and Social Networking, 13, 619-627.

Junco, R. (2012). The relationship between frequency of Facebook use, participation in Facebook activities, and student engagement. Computers \& Education, 58, 162171. DOI: 10.1016/j.compedu.2011.08.004

Kabre, F., \& Brown, U. J. (2011). The influence of Facebook usage on the academic performance and the quality of life of college students. Journal of Media and Communication Studies, 3(1), 144-150.

Kabilan, M. K., Ahmad, N., \& Abidin, M. J. Z. (2010). Facebook: An online environment for learning of english in institutions of higher education? The Internet and Higher Education, 13(4), 179-187. doi:10.1016/j.iheduc.2010.07.003

Khan, Z., \& Jarvenpaa, S. L. (2010). Exploring temporal coordination of events with facebook.com. Journal of Information Technology, 25(2), 137-151. doi: $10.1057 /$ jit.2010.8

Kirschner, P. A., \& Karpinski, A. C. (2010). Facebook and academic performance. Computers in Human Behavior, 26, 1237-1245. DOI: 10.1016/jchb.2010.03.024

Kolb, D. A. (1984). Experience as the source of learning and development. Upper Saddle River, NJ: Prentice Hall. 
Koles, B., \& Nagy, P. (2012). Facebook usage patterns and school attitudes. Multicultural Education \& Technology Journal, 6(1), 4-17.

Malesky Jr., L. A., \& Peters, C. (2012). Defining appropriate professional behavior for faculty and university students on social networking websites. Higher Education, 63, 135-151. DOI: 10.1007/s10734-011-9451-x

Mazman, S. G., \& Usluel, Y. K. (2010). Modeling educational usage of Facebook. Computer \& Education, 55(2), 444-453. Doi:10.1016/j.compedu.2010.02.008

Mazer, J. P., Murphy, R. E., \& Simonds, C. J. (2007). I'll see you on "Facebook": The effects of computer-mediated teacher self-disclosure on student motivation, affective learning, and classroom climate. Communication Education, 56(1), 1-17.

McCarthy, J. (2010). Blended learning environments: Using social networking sites to enhance the first year experience. Australasian Journal of Educational Technology, 26(6), 729-740.

Merriam, S. B. (1998). Qualitative research and case study applications in education. San Francisco, CA: Jossey-Bass.

Merriam, S. B. (2002). Qualitative research in practice. New York: John Wiley \& Sons.

Morgan, D. L. (1997). Focus groups as qualitative research (2nd ed.). Thousand Oaks, CA: Sage.

Morris, J., Reese, J., Beck, R., \& Mattis, C. (2010). Facebook usage as a predictor of retention at a private 4-year institution. Journal of College Student Retention: Research, Theory \& Practice, 11(3), 311-322.

National Association of Student Personnel Administrators. (2004). Learning reconsidered: A campus-wide focus on the student experience. Washington, DC: Author.

Pempek, T. A., Yermolayeva, Y. A., \& Calvert, S. L. (2009). College students' social networking experiences on Facebook. Journal of Applied Developmental Psychology, 30(3), 227-238. DOI: 10.1016/j.appdev.2008.12.010

Perry, W. G., Jr. (1981). Cognitive and ethical growth: The making of meaning. In A. W. Chickering (Ed.), The modern American college (pp. 76-116). San Francisco, CA: Jossey-Bass.

Quan-Haase, A., \& Young, A. L. (2010). Uses and gratifications of social media: A comparison of facebook and instant messaging. Bulletin of Science, Technology \& Society, 30(5), 350-361. 
Ryan, S. D., Magro, M. J., \& Sharp, J. H. (2011). Exploring educational and cultural adaptation through social networking sites. Journal of Information Technology Education, 10, 1-16.

Schroeder, J., \& Greenbowe, T. J. (2009). The chemistry of Facebook: Using social networking to create an online community for the organic chemistry. Innovate: Journal of Online Education, 5(4), 1-7.

Seufferheld, M. J., \& Scagnoli, N. I. (2011). Web conferencing and ICTs to enhance undergraduate science teaching. E-Learning and Digital Media, 8(1), 1-7. Retrieved from http://search.proquest.com/docview/864940409?accountid=10901

Seidman, I. (2006). Interviewing as qualitative research: a guide for researchers in education and the social sciences $\left(3^{\text {rd }} \mathrm{ed}\right)$. New York, NY: Teachers College Press.

Teclehaimanot, B., \& Hickman, T. (2011). Student-teacher interaction on Facebook: What students find appropriate. TechTrends: Linking Research and Practice to Improve Learning, 55(3), 19-30.

Trochim, W. M. K. (2005). Research methods: the concise knowledge base. Mason, OH: Cengage Learning.

Valenzuela, S., Park, N., \& Kee, K. F. (2009). Is there social capital in a social network site?: Facebook use and college students' life satisfaction, trust, and Participation1. Journal of Computer-Mediated Communication, 14(4), 875-901. doi:10.1111/j.1083-6101.2009.01474.x

Villano, M., \& Gullon, M. (2009). Student services go social. Campus Technology, 22(6), 24-27.

Wodzicki, K., Schwammlein, E., \& Moskaliuk, J. (2012). "Actually, I wanted to learn": Study-related knowledge exchange on social networking sites. Internet and Higher Education, 15(1), 9-14. doi:10.1016/j.iheduc.2011.05.008, 